\section{Pyrenean Prehistory}

ThE late M. and Mme. St. Just Péquart were well known before the Second World War as amateur prohistorians. They were at the village of Mas d'Azil during the German occupation and worked on the new gallery found in 1937, completing their investigations four years later. Mas d'Azil is in the Pyrenees; a river plunges down a valley and turns into the mountain-side, emerging just above the village. The tunnel is large enough to accommodate both the river and a road. Half-way through, to one side, there are extensive caves-so extensive indeed that it is said that during the Albigensian Wars an army took refuge in them and was not discovered. Prehistoric man used some of the galleries, and Stone Age industries have been unearthed from them. M. and Mime. St. Just Péquart had the luck to find a new gallery full of implements and fauna, some of it Aurignacian, but mostly Magdalenian in date, and including some remarkable examples of prehistoric art. Tho exact location of the gallery is described in the Annales de Paléontologie (46-49, now published in one volume), and an account is given of the section obtained; these are followed by a description of the finds-both stone and bone. The implements are very numerous and well fashioned. A number of small engraved rondels occur, as well as pieces of bone sculptured into the form of animals' heads. A few pieces of modelled clay were also found as well as a small, somewhat crude sculpture in bone of a screech owl. Many of the flat pieces of bone carry engravings of animals. But the really remarkable object is a spear thrower, the end of which is carved with a figure of a fawn looking back over its shoulder towards its tail where the head of a bird is incorporated. Very few prehistoric drawings or sculptures show an animal turning its head over its shoulder. The engraved reindeer from Laugerie Basse is an example, but the new find from Mas d'Azil is especially well executed. Many other finds of interest are described, but enough has been said to make it obvious that the Annales in which the account of the new finds appears should not be missed by prehistorians.

\section{Geological Maps of Sweden}

THE first of a new series of geological maps of Sweden, combining solid and drift geology on the scale $1: 50,000$, covers the north-eastern environs of Stockholm (Geologiska Kartblad, Serie Ae No. 1, Stockholm NO; with explanatory memoir. Pp. 148. Stockholm: Sveriges Gəologiska Undersökning, 1964. Map, 20 kr.; memoir, $5 \mathrm{kr}$.). In view of criticisms in several countries that the publications of the national geological surveys are becoming increasingly unintelligible to the intelligent layman, this map and pocket-size memoir merit recognition not only as an outstanding piece of geological cartography, but also as a praiseworthy attempt to present a descrip. tion of the geology in a comprehensive and yet readily comprehensible form. The memoir, which carries a coloured petrological map on the scale $1: 100,000$, is in Swodish, save for a seven-page English summary; both maps and all illustrations have bilingual legends. In addition to the geological features, the location of ancient monuments is shown on the map and listed in the text. Stockholm now joins the relatively few capital citiesOslo, Edinburgh and Paris are among the others-where the geological tourist is well catered for.

\section{The Macaulay Institute for Soil Research}

THE latest bound collection of scientific papers from the Macaulay Institute for Soil Researeh, published during the period 1961-63, has been issued (7. Pp. $24+$ papers 1-74. Edited by Alexa M. B. Geddes and Rosaleen Noble. Craigiebuckler, Aberdeen: The Macaulay Institute for Soil Research, 1964). The titles of 74 papers are listed in chronological order and there is an author index. The work, from seven major departments, naturally covers a wide range of topics embracing both fundamental research and the application of scientific discoveries to agricultural practice, but an idea of the scope of the publications may be gathered from the following extracts from the titles. Soil formation, the principles of the classification of soils, the genetic soil groups of Scotland; sensitivity in differential thermal analysis, various aspects of clay minerals; microbiology of rocks and weathered stones; the rate of growth of peat and its use in horticulture; the fungal metabolism of compounds related to lignin, the release of ions from minerals by fungal activity; the fractionation of organic phosphate; soil fertility, evaluation of phosphate status, effects of fertilizers on plant production; placement of radioisotopes in the study of root systems; changes in the composition of leaves during growth, aconitase activity in leaves; trace elements in soil, plant and animal.

\section{Announcements}

THE Secretary of State for Education and Science has appointed the Right Hon. Viscount Amory a member of the Medical Research Council as from October 1, in succession to the Right Hon. Lord Shawcross, whose term of membership expires in September. Lord Amory has agreed to be chairman of the Council. He was chairman of the Council during December 1960-July 1961, when he resigned on taking up his appointment as United Kingdom High Commissioner in Canada.

A symposrum on "Physiology and Biochemistry of Muscle as a Food" will be held in the University of Wisconsin during July 12-14. Further information can be obtained from E. J. Briskey, Department of Meat Science, University of Wisconsin, Madison.

AN international seminar on "Ekistics and the Future of Human Settlements", organized by the Graduate School of Ekistics, Athens, will be held in Athens during July 20-24. Further information can be obtained from Dr. D. Iatridis, Athens Center of Ekistics, 24 Strat. Syndesmou Street, Athens 136.

AN international symposium on "Swine in Biomedical Research", sponsored by the Atomic Energy Commission and the Pacific North-west Laboratories of the Battelle Memorial Institute, will be held in Richland, Washington, during July 19-21. Further information can be obtained from Dr. L. K. Bustad, Biology Department, BattelleNorthwest, P.O. Box 999, Richland, Washington.

As international conference on "The Education of Professional Physicists", arranged by the Institute of Physics and the Physical Society under the auspices of the Education Commission of the International Union of Pure and Applied Physics, will be held at the Imperial College of Science and Technology during July 15-21. Further information can be obtained from Miss $\mathbf{P}$. N. Boston, the Institute of Physics and the Physical Society, 47 Belgrave Square, London, S.W.1.

A symposium on "Thermodynamics, with Emphasis on Nuclear Materials and Atomic Transport in Solids", sponsored by the International Atomic Energy Agency and the Commission on Thermodynamics and Thermochemistry of the International Union of Pure and Applied Chemistry, will be held in Vienna during July 22-27. Further information can be obtained from Dr. C. E. Holley, jun., Division of Research and Laboratories, International Atomic Energy Agency, Kärntnerring 11, Vienna I.

Erratum. In the communication entitled "Mannosamine in the Cell Wall of Clostridium welchii (Type $A$ )", by Dr. B. T. Pickering, which appeared on p. 400 of the April 24, 1965, issue of Nature: lst para., line 10, the words "glutamic acid" should be inserted between "alanine" and "glycine". 2nd para., line 15, the first word should be "galactosamine". 